の強力な阻害剤として, アクリロニトリルブタジエンゴム 中から LAS の同族体であるドデシルベンゼンスルホン酸 を同定した. ${ }^{3}$ 市販の標準直鎖型ドデシルベンゼンスルホン 酸 $\left(\mathrm{C}_{12}\right.$ - $\left.\mathrm{LAS}\right)$ を用いて, ウシ脳 $\mathrm{CN}$ に対する阻害作用を検 討した結果, $50 \%$ 阻害濃度 $\left(\mathrm{IC}_{50}\right)$ は約 $9.3 \mu \mathrm{M}$ であり強い 阻害作用を示した. ${ }^{3}$ またラット脳 CN に対する, $\mathrm{C}_{12}$ - $\mathrm{LAS}$ 及びその類縁化合物の阻害作用について詳細な検討を試み たところ, ${ }^{4}$ ラット脳 $\mathrm{CN}$ への阻害は, $\mathrm{C}_{12}$ - $\mathrm{LAS}$ では $10 \mu \mathrm{M}$ から認められ，40 $\mu \mathrm{M}$ 以上では $\mathrm{CN}$ を完全に阻害した。一 方, ドデシル硫酸ナトリウム (SDS) は $102 \mu \mathrm{M}$ の高濃度で 漸く $32 \%$ の弱い阻害作用を示し, アルキル側鎖のないベン ゼンスルホン酸 (BS) 及び短い炭素数 8 のオクチルベンゼ ンスルホン酸 $\left(\mathrm{C}_{8}\right.$ - $\left.\mathrm{LAS}\right)$ は $105 \mu \mathrm{M}$ でも全く阻害を認めな かった. また $\mathrm{C}_{12}$ - $\mathrm{LAS}$ のラット脳 $\mathrm{CN}$ に対する $\mathrm{IC}_{50}$ は, 約 $13.5 \mu \mathrm{M}$ であった. 炭素数 10 から 14 の LAS を用いて, ア ルキル側鎖の長さの違いによるラット脳 CN 阻害の検討 では, 炭素数 12 の $\mathrm{C}_{12}$ - LAS から強い阻害が認められ, アル キル側鎖が長くなるほどその阻害作用は強くなる傾向を示 した. キネティクス解析により， $\mathrm{C}_{12}$ - L AS のラット脳 CN に対する阻害様式を求めたところ, 非競合阻害により阻害 することを明らかとし, 阻害定数 $\left(K_{\mathrm{I}}\right)$ は $\mathrm{IC}_{50}$ とほぼ同じ約 $13.8 \mu \mathrm{M}$ であった. 本研究では, $\mathrm{CN}$ と同じ PPP ファミリー の一つであるプロテインホスファターゼ 1 (PP1) に着目 し, リコンビナントウサギプロテインホスファターゼ $1 \alpha$ アイソフォーム $(\mathrm{PP} 1 \alpha)$ を用いて, $\mathrm{PP} 1 \alpha$ 活性に対する LAS の作用を詳細に検討し, ラット脳 CN との比較を行っ たので報告する.

\section{材料と方法}

\section{1. 試薬}

リコンビナントウサギプロテインホスファターゼ $1 \alpha ア$ イソフォーム $(\mathrm{PP} 1 \alpha)$ はCalbiochem/Merck (La Jolla, CA, USA), プロテインホスファターゼ 2A (PP2A) は Promega (Madison, WI, USA), リコンビナントヒト非受容体 1 型プ ロテインチロシンホスファターゼ (PTP1B) は ProspecTany TechnoGene Ltd. (Rehovot, Israel), リコンビナント バクテリオファージ $\lambda$ プロテインホスファターゼ ( $\lambda$ PP) は Santa Cruz Biotechnology, Inc. (Dallas, Texas, USA) か らそれぞれ購入した. Tris-HCl (pH7.5), Tris-HCl (pH8.0), EDTA (pH8.0) は株式会社ニッポンジーン (Toyama, Japan) から購入した. 塩化マンガン四水和物 $\left(\mathrm{MnCl}_{2} \cdot 4 \mathrm{H}_{2} \mathrm{O}\right)$, 塩 化マグネシウム $\left(\mathrm{MgCl}_{2}\right)$, 水酸化ナトリウム $(\mathrm{NaOH})$, 塩化 ナトリウム $(\mathrm{NaCl})$, パラニトロフェニルリン酸 $(p \mathrm{NPP})$, デシルベンゼンスルホン酸ナトリウム $\left(\mathrm{C}_{10}-\mathrm{LAS}\right)$, ウンデ シルベンゼンスルホン酸ナトリウム $\left(\mathrm{C}_{11}-\mathrm{LAS}\right)$, ドデシル ベンゼンスルホン酸ナトリウム $\left(\mathrm{C}_{12}\right.$ - LAS $)$, トリデシルベ ンゼンスルホン酸ナトリウム $\left(\mathrm{C}_{13}\right.$-LAS $)$, テトラデシルベ ンゼンスルホン酸ナトリウム $\left(\mathrm{C}_{14}\right.$ - LAS $)$, ドデシル硫酸ナ
トリウム $(\mathrm{SDS}), p$-オクチルベンゼンスルホン酸ナトリウ ム $\left(\mathrm{C}_{8}-\mathrm{LAS}\right)$, グリセロール及びジチオトレイトール (DTT) は和光純薬工業 (Osaka, Japan) より購入し, ベンゼンスル ホン酸ナトリウム (BS) は Aldrich 社 (St. Louis, USA) か ら購入した. 1M HEPES-NaOH (pH7.5) は Jena Bioscience (Düsseldorf, Germany) から 0.5M MOPS (pH7.5) は Alfa Aesar (Heysham, UK) から購入した.

\section{2.プロテインホスファターゼ活性の測定方法}

本実験で行ったプロテインホスファターゼ活性測定のた めの基質は $p$ NPP を用いた. $p$ NPP が脱リン酸化して生成 するパラニトロフェノール $(p N P)$ は, 中性からアルカリ性 条件で黄色を呈するため, 波長410nmにおける吸光度 $\left(\mathrm{A}_{410}\right)$ を測定することにより酵素活性の定量を行った

$\mathrm{PP} 1 \alpha$ 測定用の反応液は, $50 \mathrm{mM}$ HEPES- $\mathrm{NaOH}(\mathrm{pH} 7.5)$, $0.2 \mathrm{mM} \mathrm{MnCl}_{2}, 2 \mathrm{mM}$ DTT, $5 \mathrm{mM} p \mathrm{NPP}$ に任意の濃度の LAS, SDS あるいは BS を加え, $1.5 \mathrm{U}$ の PP1 $\alpha$ を使用して, $100 \mu \mathrm{L}$ とした. $37^{\circ} \mathrm{Cで} 60$ 分間反応を行い, $900 \mu \mathrm{L}$ の $50 \mathrm{mM}$ EDTA (pH8.0) を加えて反応を停止した.

PTP1B 測定用の反応液は, $25 \mathrm{mM}$ Tris- $\mathrm{HCl}(\mathrm{pH} 7.5), 10$ $\mathrm{mM} p \mathrm{NPP}$ に任意の濃度の LAS と $0.3 \mathrm{U}$ の PTP1B を加え て $50 \mu \mathrm{L}$ とした. $37^{\circ} \mathrm{Cで} 30$ 分間反応を行い, $50 \mu \mathrm{L}$ の $1 \mathrm{M}$ $\mathrm{NaOH}$ を加えて反応を停止した.

PP2A の測定に関しては, reaction buffer $(50 \mathrm{mM}$ Tris$\mathrm{HCl}(\mathrm{pH} 8.0), 20 \mathrm{mM} \mathrm{MgCl}_{2}$ ) を使用して $14 \mathrm{mM} p \mathrm{NPP}$ 溶液 を調製し, enzyme dilution buffer (20mM MOPS (pH7.5), $150 \mathrm{mM} \mathrm{NaCl}, 1 \mathrm{mM} \mathrm{MgCl}, 0.1 \mathrm{mM} \mathrm{MnCl}_{2}, 10 \mathrm{v} / \mathrm{v} \%$ グリセ ロール）を使用して PP2A の希釈調製を行った. 反応液は, $11.2 \mathrm{mM} p \mathrm{NPP}$ に任意の濃度の LAS と $0.2 \mathrm{U}$ の PP2A を加 えて $100 \mu \mathrm{L}$ とした. $37^{\circ} \mathrm{Cで} 30$ 分間反応を行い, $25 \mu \mathrm{L}$ の $1 \mathrm{M} \mathrm{NaOH}$ を加えて反応を停止した.

$\lambda \mathrm{PP}$ 測定用の反応液は, $50 \mathrm{mM}$ Tris- $\mathrm{HCl}(\mathrm{pH} 7.5), 0.2 \mathrm{mM}$ $\mathrm{MnCl}_{2}, 10 \mathrm{mM} p \mathrm{NPP}$ に任意の濃度の LAS と $10 \mathrm{U}$ の $\lambda \mathrm{PP}$ を加えて $200 \mu \mathrm{L}$ とした. $30^{\circ} \mathrm{Cで} 20$ 分間反応を行い, $800 \mu \mathrm{L}$ の $62.5 \mathrm{mM} \mathrm{EDTA}(\mathrm{pH} 8.0)$ を加えて反応を停止した.

\section{PP $1 \alpha$ に対するLAS のキネティクス解析}

PP1 $\alpha$ に対する LAS の阻害様式を決定するため, $\mathrm{C}_{12}{ }^{-}$ LAS を用いて濃度を $0 \mu \mathrm{M}, 13 \mu \mathrm{M}$ に固定し, 様々な基質濃 度 $(p \mathrm{NPP})$ の存在下における PP $1 \alpha$ 活性の測定を行った. 阻害様式は, 基質濃度 $[p \mathrm{NPP}]$ を変化させた時に得られた 速度 $V_{0}$ (formed $\left.p \mathrm{NP} \mathrm{nmol} / \mathrm{min}\right)$ と基質濃度 $[p \mathrm{NPP}]$ の 両逆数プロット解析から決定した. ${ }^{5}$

\section{結果}

\section{1.アルキルベンゼンスルホン酸と炎の類縁化合物の PP $1 \alpha$ 阻害}

最初にアルキルベンゼンスルホン酸の中でも $\mathrm{C}_{12}$ - LAS 


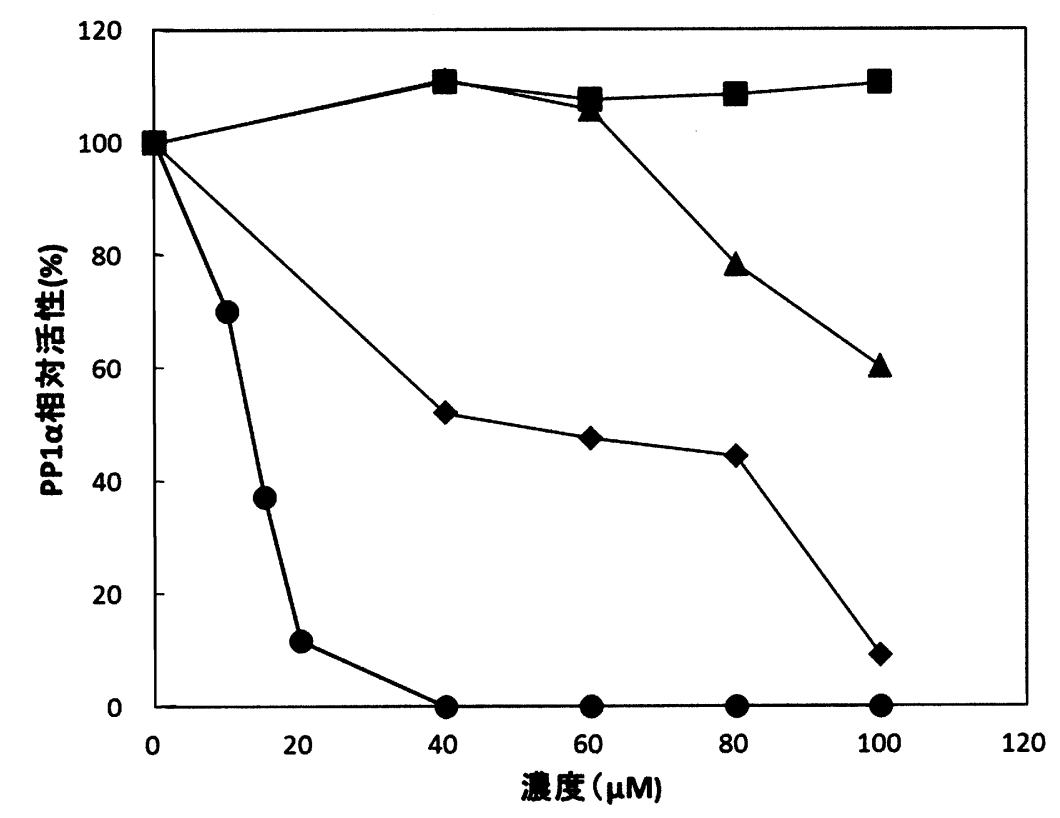

図 2 アルキルベンゼンスルホン酸とその類縁化合物の PP $1 \alpha$ 活性の影響

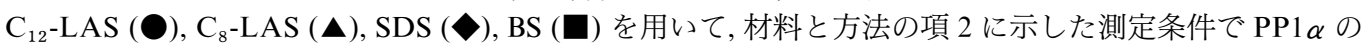
活性を測定した.グラフの横軸は添加したそれぞれの化合物の濃度 $(\mu \mathrm{M})$ を表し, 縦軸は化合物無添加の 活性を $100 \%$ とした相対活性で示した.

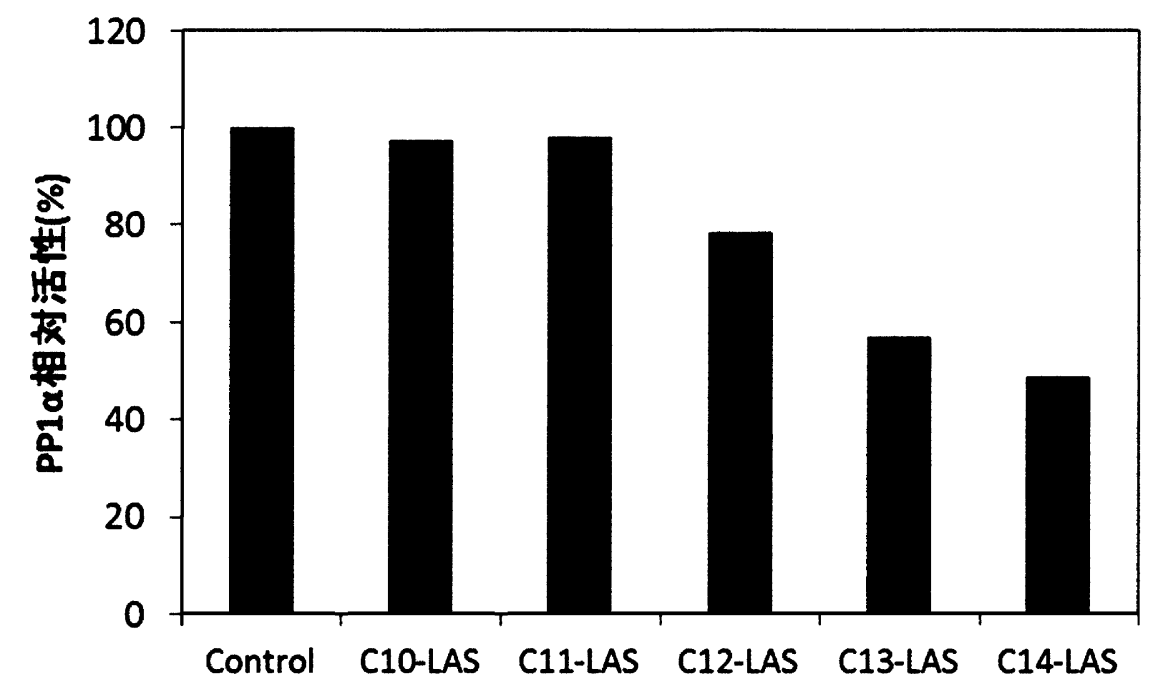

図 3 アルキルベンゼンスルホン酸同族体の PP $1 \alpha$ 活性に対する阻害作用の影響

アルキル側鎖の炭素数 10 から 14 のアルキルベンゼンスルホン酸 (LAS) $10 \mu \mathrm{M}$ をそれぞれ用いて, 材料 と方法の項 2 に示した測定条件で PP $1 \alpha$ の活性を測定した. グラフの縦軸は LAS 無添加の活性を $100 \%$ とした相対活性で表した.

を用い PP $1 \alpha$ 活性に対する影響を検討したところ, CN と 同様に阻害作用が $10 \mu \mathrm{M}$ から認められ，40 $\mu \mathrm{M}$ 以上では PP1 $\alpha$ を完全に阻害し, $50 \%$ 阻害濃度 $\left(\mathrm{IC}_{50}\right)$ は約 $13.2 \mu \mathrm{M}$ であった (図 2). LAS の類縁化合物である SDS, BS, $\mathrm{C}_{8}$ LAS について同様に検討を行ったところ (図 2), SDS は $40 \mu \mathrm{M}$ から阻害作用を認め, $100 \mu \mathrm{M}$ では PP $1 \alpha$ を完全に阻 害した. 一方, 炭素数 8 の $\mathrm{C}_{8}$ - LAS では $80 \mu \mathrm{M}$ から阻害作 用を認め, アルキル基のない BSでは阻害作用を認めな かった. 従って, 次にアルキル側鎖の長さの違いによる PP $1 \alpha$ 阻害の詳細な解析を試みた。炭素数 10 から 14 の
LAS を用いて, $10 \mu \mathrm{M}$ における PP $1 \alpha$ 阻害をそれぞれ測定 した結果, 炭素数 10 の $\mathrm{C}_{10}$ - LAS 及び炭素数 11 の $\mathrm{C}_{11}$-LAS は阻害を示さなかったが, 炭素数 12 の $\mathrm{C}_{12}$-LAS から阻害 作用を認め, アルキル側鎖が長くなるほどその阻害作用は 強くなり (図 3), $C_{14}$ - LAS ではコントロールの $50 \%$ の阻害 を示した

\section{PP $1 \alpha$ に対する $\mathrm{C}_{12}$-LAS のキネティクス解析}

$\mathrm{C}_{12}$-LAS の濃度を $0 \mu \mathrm{M}, 13 \mu \mathrm{M}$ の 2 点で固定し, 様々な 濃度の基質 $p$ NPP を用いて PP $1 \alpha$ 活性を測定した. 測定か 


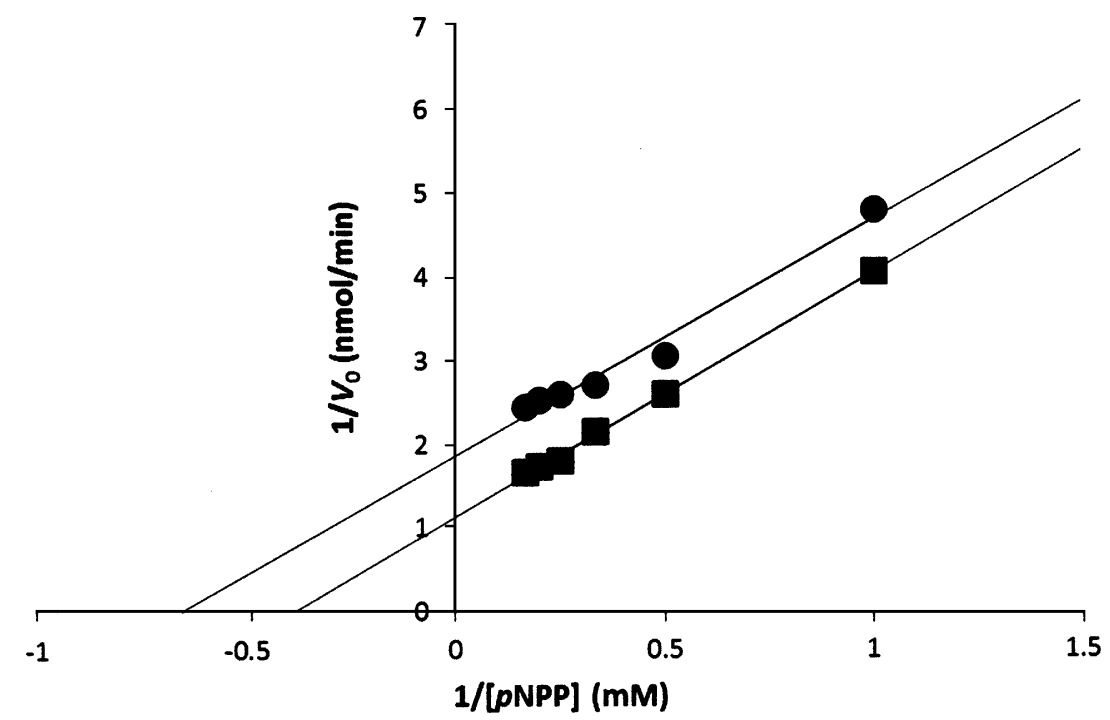

図 4 逆数プロット解析

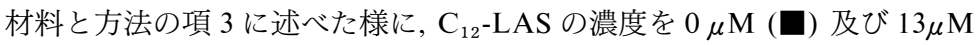

に示したように基質 $p$ NPP の濃度を変えてPP1 $\alpha$ 活性をそれぞれ湘定した 得られた点で固定し，グラフ $p \mathrm{NP} \mathrm{nmol} / \mathrm{min})$ と基質 $p \mathrm{NPP}$ 濃度の両逆数プロットを行った.

ら得られた酵素反応速度 $V_{0}$ (formed $\left.p \mathrm{NP} \mathrm{nmol} / \mathrm{min}\right)$ と基 質 $p$ NPP の濃度の両逆数プロットを求めたところ, 2 つの 直線はほぼ平行を示し (図 4), この結果から, $\mathrm{C}_{12}$ - LAS によ るPP $1 \alpha$ の阻害は不競合阻害であることが示唆された. ${ }^{5}$ また図 4 のグラフから阻害剤が存在しないときの最大反応 速度 $V_{\max }$ は約 $0.88 \mathrm{nmol} / \mathrm{min}$, ミカエリス定数 $\left(K_{\mathrm{M}}\right)$ は約 2.6 $\mathrm{mM}$ であり, $\mathrm{C}_{12}$-LAS $13 \mu \mathrm{M}$ の存在下では $V_{\max }$ は約 0.54 $\mathrm{nmol} / \mathrm{min}$, みかけの $K_{\mathrm{M}}$ は約 $1.5 \mathrm{mM}$ であった. また PP $1 \alpha$ に対する $\mathrm{C}_{12}$-LASの阻害定数 $\left(K_{\mathrm{I}}\right)$ は約 $19 \mu \mathrm{M}$ であった (表1).

表 $1 \quad \mathrm{PP} 1 \alpha$ の $p$ NPP に対する $K_{\mathrm{M}}, V_{\max }, K_{\mathrm{I}}$

\begin{tabular}{lcccc}
\hline & $K_{\mathrm{M}}(\mathrm{mM})$ & $V_{\max }(\mathrm{nmol} / \mathrm{min})$ & $K_{1}(\mu \mathrm{M})$ \\
\hline $\mathrm{C}_{12}$ - LAS $(0 \mu \mathrm{M})$ & 2.6 & 0.88 & \\
$\mathrm{C}_{12}$ LAS $(13 \mu \mathrm{M})$ & 1.5 & 0.54 & 19 \\
\hline
\end{tabular}

\section{3. $\mathrm{C}_{12}$-LAS の $\lambda \mathrm{PP}, \mathrm{PP} 2 \mathrm{~A}, \mathrm{PTP} 1 \mathrm{~B}$ に対する阻害作用}

先行研究において LAS はPP2B であるカルシニューリ

ン $(\mathrm{CN})$ を阻害し, ${ }^{3,4}$ 本研究において新たにPP $1 \alpha$ を阻害 することが示された．また $\mathrm{C}_{12}$ - LAS に対する $\mathrm{IC}_{50}$ は，ウシ 脳 $\mathrm{CN}$ で約 $9.3 \mu \mathrm{M}$, ラット脳 $\mathrm{CN}$ で約 $13.5 \mu \mathrm{M}, \mathrm{PP} 1 \alpha$ で約

表 2 各種プロテインホスファターゼに対する $\mathrm{C}_{12}$-LAS の $50 \%$ 阻害濃度

\begin{tabular}{lc}
\hline \multicolumn{1}{c}{ 酵素 } & $50 \%$ 阻害濃度 $\left(\mathrm{IC}_{50}\right)(\mu \mathrm{M})$ \\
\hline ウシ脳 $\mathrm{CN}^{1}$ & 9.3 \\
ラット脳 $\mathrm{CN}^{2}$ & 13.5 \\
PP1 $\alpha$ & 13.2 \\
PP2A & 70.0 \\
$\lambda$ PP & 25.0 \\
PTPIB & 3.0 \\
\hline
\end{tabular}

1 は文献 3, 2 は文献 4 より引用.
$13.2 \mu \mathrm{M}$ であった. そこで, 他のプロテインホスファターゼ ( $\lambda$ PP, PP2A, PTP1B) に打ける $\mathrm{C}_{12}$-LAS の影響について $\mathrm{IC}_{50}$ を求めることにより検討を行った. 表 2 に示すように $\lambda \mathrm{PP}$ で約 $25 \mu \mathrm{M}, \mathrm{PP} 2 \mathrm{~A}$ は約 $70 \mu \mathrm{M}, \mathrm{PTP} 1 \mathrm{~B}$ は約 $3 \mu \mathrm{M}$ であ り, 3 つの酵素で $\mathrm{C}_{12}$-LAS による阻害作用を認めた。

\section{考察}

生体内におけるタンパク質のリン酸化状態は, プロテイ ンキナーゼとプロテインホスファターゼによって厳密にコ ントロールされ, 細胞機能の維持, 制御において重要な役 割を果たしている. プロテインホスファターゼである PP1 は, PP2A, PP2B とともにホスホプロテインホスファター ゼ (PPP) ファミリーの一つであり, セリン/トレオニンホ スファターゼとして知られている. PPP ファミリーの構造 上の特徵は, 触媒サブユニットと調節サブユニットとが会 合するホロ酵素であり, 哺乳動物細胞では PP1 触媒サブユ ニットには 3 種類 $(\alpha, \gamma, \delta)$ のアイソフォームが存在する. また, PP1には 100 種類以上の調節サブユニットが存在し ており, PP1 との複合体を形成することにより, PP1の 様々な生理機能が発揮される, 6,7 さに PP1 には, 内在性 阻害タンパク質 (I-1 (inhibitor-1), CPI-17 (protein kinase C-potentiated phosphatase inhibitor of $17 \mathrm{kDa}$ ), DARPP-32 (dopamine and cAMP-regulated phosphoprotein $32 \mathrm{kDa}$ ) な ど）が見出されており, これらの阻害タンパク質によって もホスファターゼ活性は制御されている.8

先行研究において, 我々は, PPPの一つであり PP2B と も呼ばれている CN の強力な阻害剈として, アクリロニト リルブタジエンゴム中から直鎖アルキルベンゼンスルホン 酸 $(\mathrm{LAS})$ の同族体であるドデシルベンゼンスルホン酸を 
同定した. ${ }^{3}$ 市販の標準直鎖型ドデシルベンゼンスルホン酸 $\left(\mathrm{C}_{12}\right.$ - $\left.\mathrm{LAS}\right)$ を用いて, ウシ脳およびラット脳 $\mathrm{CN}$ に対する 阻害作用を検討した結果, $\mathrm{C}_{12}$ - LAS はそれぞれの CN に対 して強い阻害作用を示した. ${ }^{3,4}$ 本研究では同じPPP ファミ リーの中でも PP1 に着目し, PP1 $1 \alpha$ アイソフォムを用い て LAS のホスファターゼ活性に与える影響を検討した.

最初に $\mathrm{C}_{12}$-LAS を用いて PP $1 \alpha$ 活性に対する阻害作用 を検討したところ, $10 \mu \mathrm{M}$ から阻害作用を認め, $\mathrm{IC}_{50}$ はラッ 卜脳 CN とほぼ同じ約 $13.2 \mu \mathrm{M}$ であった. また,アルキル側 鎖の長さに対する PP $1 \alpha$ の影響を調べたところ, 側鎖の長 いほうがより PP1 $\alpha$ に対して強い阻害作用を示し, 先行研 究のラット脳 $\mathrm{CN}$ の結果と一致した. ${ }^{4}$ 次に, PP1 $\alpha$ に対し て LAS の類縁化合物 (SDS, $\mathrm{C}_{8}$-LAS, BS) について $100 \mu \mathrm{M}$ までの濃度で検討を行ったところ, BS では阻害作用を認め なかったが, $\mathrm{C}_{8}$-LAS では $80 \mu \mathrm{M}$ から弱い, SDS では $40 \mu \mathrm{M}$ から中程度の阻害作用を認め, ウシ脳およびラット脳 CN とは少し異なる結果となった. LAS の阻害様式を調べるた め $\mathrm{C}_{12}$ - LAS を用いてキネティクス解析を行ったところ, 意 外にも不競合阻害を示し，ラット脳 CN の非競合阻害とは 異なる阻害様式を示すことが明らかとなった．非競合阻害 は基質が酵素に結合していても，あるいは結合していなく ても起こりうる阻害であるのに対して，不競合阻害は，阻 害剤が酵素と基質との間で形成される複合体にのみ結合す る時に起こることが知られている.この結果, 酵素の基質 に対する見かけの $K_{\mathrm{M}}$ は低下し， $V_{\max }$ を低下させるが, 本研 究においても $13 \mu \mathrm{M}$ の $\mathrm{C}_{12}$-LAS で $p$ NPP に対する $K_{\mathrm{M}}$ が 約 $2.6 \mathrm{mM}$ から約 $1.5 \mathrm{mM}, V_{\text {max }}$ が約 $0.88 \mathrm{nmol} / \mathrm{min}$ から約 $0.54 \mathrm{nmol} / \mathrm{min}$ へと変化した. 同じ PPP ファミリーであり ながら PP1 $\alpha$ と PP2B で阻害様式が異なる理由について検 討は, 今後の研究課題であると考えられる. 次に, 他のプロ テインホスファターゼ ( $\mathrm{PP}, \mathrm{PP} 2 \mathrm{~A}, \mathrm{PTP} 1 \mathrm{~B})$ における $\mathrm{C}_{12}$-LAS の影響について $\mathrm{IC}_{50}$ を求めることにより検討を 行った. $\lambda \mathrm{PP}$ はバクテリオファージ $\lambda$ が持っている $\mathrm{Mn}^{2+}$ 依存性プロテインホスファターゼで, リン酸化されたセリ ン, トレオニン，チロシンに対して活性を示すのが特徵で ある. ${ }^{9}$ また, PP2AはPPPファミリーの一つであり, PTP1Bは 非受容体型プロテインチロシンホスファターゼであり，一 般にインスリンシグナルを抑制的に制御するホスファター ゼであることが知られている. ${ }^{10,11}$ 表 2 に示したように $\lambda \mathrm{PP}$ の $\mathrm{IC}_{50}$ は約 $25 \mu \mathrm{M} ， \mathrm{PP} 2 \mathrm{~A}$ は約 $70 \mu \mathrm{M} ， \mathrm{PTP} 1 \mathrm{~B}$ は約 3 $\mu \mathrm{M}$ であり, 本実験で検討したプロテインホスファターゼ 全てにおいて程度の差はあるが, $\mathrm{C}_{12}$-LAS による阻害作用 を認めた. 従って, LAS はプロテインホスファターゼ全般 に阻害剤作用を示す化合物である可能性が考えられる. 代 表的なプロテインホスファターゼの阻害剤としてオカダ酸 がよく知られているが, オカダ酸はセリン/トレオニンホ スファターゼである PPP ファミリーに対して強い阻害作 用を示す. ${ }^{12}$ 本結果において興味深いのは, LAS はオカダ 酸とは異なり, セリン/トレオニンホスファターゼよりも
チロシンホスファターゼに対して強い阻害作用を持ってい る可能性がある. 今後はさらに, LAS の受容体型チロシン ホスファターゼなどに対する阻害作用の検討などを重ね, この点も明らかとしていきたいと考える.

\section{結語}

$\mathrm{C}_{12}$-LAS は CN と同様に, PP1 $\alpha$ についても低濃度で阻 害作用を示した.アルキル側鎖の炭素数 12 から 14 の LAS は，側鎖が長くなるほど PP $1 \alpha$ を強く阻害した. $\mathrm{C}_{12}$-LAS のPP1 $1 \alpha$ に対する阻害様式は不競合阻害であり，ラット脳 $\mathrm{CN}$ に対する阻害様式と異なることが明らかとなった. $\lambda \mathrm{PP}, \mathrm{PP} 2 \mathrm{~A}, \mathrm{PTP} 1 \mathrm{~B}$ の $\mathrm{IC}_{50}$ から $\mathrm{C}_{12}$-LAS はプロテインホ スファターゼ全般に阻害剤作用を示す化合物である可能性 が考えられる.

\section{謝辞}

本研究の一部は日本科学技術研究費 (挑戦的萌芽研究 AS232Z01008G 及び基盤研究 (C) 26340027) の助成を受け たものです.

\section{文献}

1. 経済産業省経済産業政策局調査統計部 化学工業統計年報, 2004.

2. CERI 有害性評価書 直鎖アルキルベンゼンスルホン酸及 びその塩 財団法人化学物質評価研究機構安全性評価技術 研究所, 2006.

3. Ito N, Tokita M, Hosaka K, et al. Identification of alkylbenzene sulfonate surfactants leaching from an novel inhibitors of calcineurin activity. Biosci Biotechnol Biochem 2013; 77: 954-960.

4. 伊藤 昇, 時田佳治, 保坂公平ら. アルキルベンゼンスルホ ン酸のラット脳カルシニューリン活性への阻害作用に関す る研究. 北関東医学 2014; 64: 23-29.

5. Voet D, Voet JG. Biochemistry 4 th edition. New York: John Wiley \& Sons Inc., 2011: 492-496.

6. Virshup DM, Shenolikar S. From promiscuity to precision: protein phosphatases get a makeover. Mol Cell 2009; 33: 537-545.

7. Bollen M, Peti W, Ragusa MJ, et al. The extended PP1 toolkit: designed to create specificity. Trends Biochem Sci 2010; 35: 450-458.

8. Mansuy IM, Shenolikar S. Protein serine/threonine phosphatases in neuronal plasticity and disorders of learning and memory. Trends Neurosci 2006; 29: 679-686.

9. Zhuo S, Clemens JC, Hakes DJ, et al., Expression, purification, crystallization, and biochemical characterization of a recombinant protein phosphatase. J Biol Chem 1993; 268: 17754-17761.

10. Tonks NK, Neel BG. Combinatorial control of the specificity of protein tyrosine phosphatases. Curr Opin Cell 
Biol 2001; 13: 182-195.

11. Ostman A, Böhmer FD. Regulation of receptor tyrosine kinase signaling by protein tyrosine phosphatases. Trends Cell Biol 2001; 11: 258-266.

12. Fernández JJ, Candenas ML, Souto ML, et al. Okadaic acid, useful tool for studying cellular processes. Curr Med Chem 2002; 9: 229-262. 


\title{
Characterization of Alkylbenzene Sulfonate Inhibitors of Protein Phosphatase $1 \alpha$ Activity
}

\author{
Noboru Ito ${ }^{1}$, Toru Nakajima ${ }^{2}$, Takahiro Sugai ${ }^{1}$, Noriyuki Yamagiwa ${ }^{3}$, \\ Junko Nakajima-Shimada ${ }^{1}$, Kohei Hosaka ${ }^{1}$ and Susumu Tanaka ${ }^{2}$ \\ 1 Gunma University Graduate School of Health Sciences, 3-39-22 Showa-machi, Maebashi, Gunma 371-8514, Japan \\ 2 Department of Health and Nutrition, Takasaki University of Health and Welfare, 37-1 Nakaorui-machi, Takasaki, Gunma 370-0033, \\ Japan \\ 3 Department of Pharmacy, Takasaki University of Health and Welfare, 60 Nakaorui-machi, Takasaki, Gunma 370-0033, Japan
}

Background \& Aims: Protein phosphatase 1 (PP1) is a member of the phosphoprotein phosphatase (PPP) family which, together with protein phosphatase $2 \mathrm{~A}$ and protein phosphatase 2B (PP2B), exhibits serine/threonine phosphatase activity. We previously reported that linear alkylbenzenesulfonates (LAS) noncompetitively inhibit the phosphatase activity of calcineurin $(\mathrm{CN})$, also known as PP2B. Here we examined the inhibitory effect of LAS on PP1 $\alpha$ activity and determined the mechanism of inhibition.

Methods: The inhibitory effect of LAS against PP1 $\alpha$ enzymatic activity was confirmed using $p$ nitrophenylphosphate as a substrate and was further examined by kinetic analysis.

Results: $\mathrm{C}_{12}$-LAS to $\mathrm{C}_{14}$-LAS exhibited strong inhibitory effects for PP1 $\alpha$. The half maximal inhibitory concentration $\left(\mathrm{IC}_{50}\right.$ ) value of $\mathrm{C}_{12}$-LAS was $13.2 \mu \mathrm{M}$. Using a double-reciprocal plot, $\mathrm{C}_{12}$-LAS was determined to exhibit uncompetitive inhibitory effects on $\mathrm{PP} 1 \alpha$ activity.

Conclusions: LAS analogues containing twelve to fourteen carbons in the alkyl side chain showed strong inhibitory effects against both PP1 $\alpha$ and CN. Although LAS shows noncompetitive inhibition for CN, our results demonstrate that it exhibits uncompetitive inhibition for $\mathrm{PP} 1 \alpha$.

\footnotetext{
Key words:

protein phosphatase $1 \alpha$,

calcineurin,

alkylbenzene sulfonates,

uncompetitive inhibition
} 